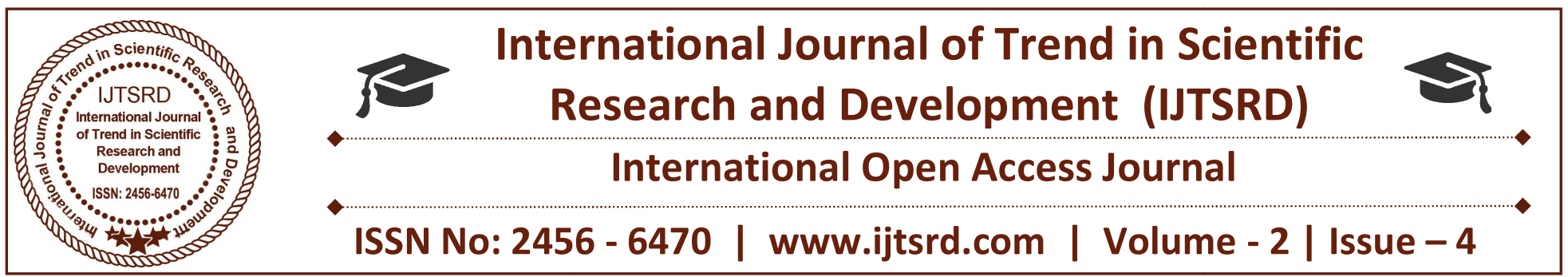

\title{
The Influence of the use of Instructional Resources in the Teaching of Mathematics on Students' Performance in Mathematics in Public English Speaking Secondary Schools in the South West Region of Cameroon
}

\author{
Besong Francis Mbeng \\ Ph.D. in View, University of Buea, Buea, Cameroon
}

\section{ABSTRACT}

It has been suggested that teachers instructional practices mediate the relationship between teacher background variables and student learning (Fennema\&Franke, 1992; Mewborn \& Cross, 2007). One instructional practice that has been supported as a way to help build students' mathematical understanding is the use of instructional resources (e.g., Hiebertet al., 1997). In this dissertation, it is investigated the influence of the use of instructional resources on the teaching of mathematics as a mediator of the relationship between teacher variables and students' mathematics learning. A survey design employing a mixed-method approach, quantitative and qualitative, was used. In this research, 408 students sampled from both urban and rural areas in the six divisions that make up the South West region of Cameroon, 8 focus group discussions were organized and 12 observations were done. Instruments for data collection were a semi-structured questionnaire, a focus group discussion guide and an observational guide. As concerns questionnaire and observation, the data for the closed ended questions were described using frequency, proportion and Multiple-Responses-Analysis to aggregate score within conceptual components while hypotheses were tested using logistic regression model with the statistical package of social science version 21.0.(SPSS). Qualitative data were analysed following the thematic approach. Though the study revealed that the performance of students in mathematics was generally good $80.6 \%$ (329), the contribution of instructional resources was perceived to be weak and

statistically non-significant. From both students and observation perspectives, print media were not effectively used, as only $22.9 \%$ weight from the observation and $19.4 \%$ (79) of students agreed that they were used to a high extent. Only $15.7 \%$ (64) of the students acknowledged that they were effectively available. In the same line, $68.9 \%$ (281) students were of the opinion that mathematic laboratories were not used at all while $73.5 \%$ (300) denounced the fact that computer laboratories were not used at all. Though students for the majority agreed that libraries equipped with books are available in schools for the teaching of mathematics $65.2 \%$ (266), only $15.2 \%$ (62) stated that they were effectively used for the teaching of mathematics. it was perceived that projected audio-visual instructional resources in the teaching of mathematics were not at all used, as generally perceived by the students $82.4 \%$ (336). It was then recommended that teachers and students should be drilled on the importance and usage of instructional resources. Those instructional resources should be made available to make the teaching of mathematics more practical and take advantage from the assets offered by ICTs, notably computer-based simulations and modeling.

\section{INTRODUCTION}

Mathematics is a hall-mark and the most enduring artefact of any community. Mathematics is a hallmark because it is interrelated to other subjects. There is absolutely nothing we can do in life without involving mathematics. With the changing times and trends, today's mathematics teachers are experiencing major changes not only in the mathematics content they teach, but also in the way they teach. It would 
appear teachers came through school when mathematics consisted of a collection of facts and skills to be memorised or mastered by a relatively homogeneous group of students taught using a lecture approach.

The NCTM (National Council Teachers of Mathematics) also recognized that students construct their knowledge through experience by engaging in meaningful and purposeful activities. In Standardsbased instruction, "knowing" mathematics is defined as "doing" mathematics (Greeno, 2003). Concerning the methods of instruction, the Standards emphasized problem solving as a means of learning mathematics, rather than using problems to practice procedures that have already been learned (Hiebert, 2003; Klein, 2007; Schoenfeld, 2004).

\section{Aims of the Study}

There isn't much literature in relation to the Influence of the Use of Instructional Resources in the Teaching of Mathematics on Students' Performance in Mathematics in Public English Speaking Secondary Schools .However, the use of instructional resources in mathematics instruction will be explored in more detail in the ensuing sections of this article. This research took place in Cameroon but has focused very largely on public English speaking secondary schools in the South West region of Cameroon. There isn't much scholarly work, on the Influence of the Use of Instructional Resources in the Teaching of Mathematics on Students' Performance in Mathematics in Public English Speaking Secondary Schools. The absence of research works in this specific area poses challenges for this study in that there is no text blueprint for investigating use of instructional resources for mathematics instruction in Cameroon and therefore, a road map need to be established in this direction. A further issue that needs to be addressed in the study aims are the views of students and teachers in Cameroon on the influence of the use of instructional resources in the teaching of mathematics on students' performance. This research work is aimed at creating a platform on which further research works in Cameroon can be carried out .The task of creating a base for further research is dependent on conducting core empirical research and it is to this end that emerged the basis of the aims of this study viz: The study seeks to examine the influence of the use of instructional resources in terms of availability, accessibility, ability to use and extent of usage on the teaching of mathematics in Public
English Speaking Secondary Schools in the South West Region of Cameroon.

\section{The Research Question}

The above aims translate into one set of research question. This research question will inform the framework of the study and guide the methodological approach and structure of the research study itself. To what extent are instructional resources used in public English Speaking Secondary Schools in the South West Region of Cameroon? In this introduction, the study is firstly placed in context, providing a justification for the research. Secondly, the purpose, aims and research question is presented. What will follow is an outline of subsequent headings presenting the wider literature review. Literature from a range of relevant topics is synthesized in order to provide a fuller understanding of this research field. Thirdly; the research design traditions deployed, the analysis of the field document and interview transcripts and the ethical considerations are presented. Finally, the findings and discussions of the data are discussed and conclusions.

\section{REVIEW OF RELATED LITERATURE}

Mathematics is the study of quantity, structure and change (i.e. arithmetic, algebra, geometry \& analysis). The word Mathematics comes from the Greek word $\mu \alpha^{e e} \theta \eta \mu \alpha$ (mthma) which means learning, study and science. Mathematics begins from many different breed of problems. Initially, these were found in commerce, land measurement, architecture and afterward, in astronomy. But today, all sciences recommend problems studied by mathematicians and many problem arises within mathematics itself. Mathematics is used all over the world as an essential tool in many fields including natural science, engineering, medicine and the social sciences. Applied Mathematics is a branch of mathematics that is concerned with application of mathematical knowledge to other fields. It enthuses of new mathematical discoveries and sometimes leads to the growth of exclusively new mathematical disciplines like statistics and game theory.

Many philosophers believe that mathematics is not experimentally falsifiable and not a science. In 1930, Gödel's incompleteness theorems persuaded many mathematicians that mathematics can't be reduced to logic alone. Karl Popper concluded that most mathematical theories are hypothetico-deductive like those of Physics and Biology. Pure Mathematics, therefore, turns out to be much closer to the natural 
sciences whose hypotheses are conjectures than it seemed even recently.

Many mathematical objects, such as sets of numbers and functions, exhibit internal structure as a consequence of operations or relations that are defined on the set. Mathematics then studies properties of those sets that can be expressed in terms of that structure; for instance number theory studies properties of the set of integers that can be expressed in terms of arithmetical operations. Probably mathematics is the only subject which offers misunderstanding between teacher and pupil. The teacher stands at the blackboard. It is perfectly clear to him what the symbols mean and what the conclusion can be drawn from them, but it may be completely otherwise with many of the students. Majority of students discover mathematics as a daunting subject. Such problems may crop up as a result of improper guidance in their initial stages. Efforts may not be taken by their teachers to treat their fear while they were small. And that fear keeps the students away from mathematics as they grown up. Since the subject needs a lot of practices and understandings, the students who don't remain in touch with it regularly, they don't seem to do well in examinations. As a result their fear remains for whole life. Education, according to Coombs (1970) consists of Stwo components. He classified these two components into inputs and outputs. According to him, inputs consist of human and material resources and outputs are the goals and outcomes of the educational process. Both the inputs and outputs form a dynamic organic whole and if one wants to investigate and assess the educational system in order to improve its performance, effects of one component on the other must be examined. Instructional resources which are educational inputs are of vital importance to the teaching of any subject in the school curriculum. Wales (1975) was of the opinion that the use of instructional resources would make discovered facts glued firmly to the memory of students.

Savoury (1958) also added that, a well-planned and imaginative use of visual aids in lessons should do much to banish apathy, supplement inadequacy of books as well as arouse students' interest by giving them something practical to see and do, and at the same time helping to train them to think things out themselves. Scarcity of textbooks, libraries and physical facilities according to Coombs (1970), will constraint educational system from responding more fully to new demands. In order to raise the quality of education, its efficiency and productivity, better learning materials and resources are needed. Knezewich (1975) also stressed the importance of having appropriate personnel plan and adequate instructional materials and physical facilities to support educational effort.

The school structure might probably affect the way instructional resources correlates with the teaching of mathematics in secondary schools. A well organized structure will enhance the teaching- learning process while a disorganized structure wills mare the activities, the efforts of teachers, learners and all stakeholders.

The formal education system in Cameroon is predominantly academic and hierarchically divided, ranging from primary to tertiary level. The current structure of education is $2-6-5-2-3+$, that is, two years of pre-primary education, six years of primary education, five years of ordinary level secondary $(\mathrm{O}$ level) education, two years of advanced level secondary (A level) education and finally, a minimum of 3 years of university education. The following section describes the formal education structure in Cameroon.

\section{The Use of Instructional Resources and the} teaching of mathematics

Material resources include textbooks, charts, maps, audiovisual and electronic instructional materials such as radio, tape recorder, television and video tape recorder and many others. Other category of material resources consist of paper supplies and writing materials such as pens, eraser, exercise books, crayon, chalk, drawing books, notebooks, pencil, ruler, slate, workbooks and so on (Atkinson ,2000). (Newton ,1997) professed that the magnitude of instruction are more scientific base; make instruction more powerful; make learning more immediate and finally make access to education more equal. Adeogun (2001) discovered a very strong positive significant relationship between instructional resources and academic performance. According to Adeogun, schools endowed with more resources performed better than schools that are less endowed. This corroborated the study by (Babayomi, 1999) that private schools performed better than public schools because of the availability and adequacy of teaching and learning resources. (Adeogun, 2001) discovered a low level of instructional resources available in public schools and stated that our public schools are starved of both teaching and learning resources. He expresses 
that effective teaching cannot take place within the classroom if basic instructional resources are not present. Fuller (1986) suggested that the quality of instructional processes experienced by a learner determines quality of education. Mwiria (1985) also supports that students performance is affected by the quality and quantity of teaching and learning resources. The author noted that institutions with adequate facilities such as textbooks stand a better chance of performing well in examination than poorly equipped ones.

A study conducted by (Gogo, 2002) on the input of cost sharing on access, equity and quality of secondary education in Rachuonyo district found that the quality of education had remained average for the entire period 1996 to 1999. The author concluded that performance could be attributed to inadequate teaching and learning materials and equipment. In addition, Gogo recommended that in order to provide quality education the availability of relevant teaching /learning materials and facilities is crucial. Ayot (1984) suggested that all that is heard and seen, only about 10 percent through the sense of hearing is retained and 80 percent or more through seeing. In this consideration, it would appear likely that the inadequacy of learning facilities affects the quality of education and subsequently learner's performance. Muthamia (2009) concurs with the above findings that, good performance demanded that every learning institution be equipped with relevant and adequate text books. According to teachers can only be effective and productive in their work if they have adequate and relevant facilities. In addition, instructional resources such as textbook and science equipment for both teachers and students are key variables in student's learning and performance at all school levels

\section{THE ORETICAL AND CONCEPTUAL FRAMEWORK}

In this study, the theoretical framework also used is the socio cultural theory. Researcher such as (Lantolf, 2000) is of the view that Vygotsky came up with the idea of socio cultural theory some years after the Russian revolution. Since the development of socio cultural theory, various researchers have used it in the field of mathematics.

Although Vygotsky died in 1934, his work was done in the early decades of the last century. Vygotsky's work on socio cultural theory only became known in the west and translated much later after his death. (Vygotsky, 1978) emphasises that child's learning involves a form of mediation between the learner, social, cultural and historical context. In the days of Vygotsky, educators were of the assumption that effective learning is learners' attainment of a level of threshold of development in the performance of tasks especially in mathematics.

However, (Vygotsky, 1978, 1993) argues that the understanding and the determination of the child's development level are best by identifying what such a child could do under the guidance of a more competent person within a socio cultural and historical context. The child learns, and increases knowledge, through interaction with the physical and social environment. Accordingly, a child develops mentally as he or she interacts with parents, siblings and other people around. Learners learn mathematics better when they use instructional resources in socialinteraction with adults and peers who are more knowledgeable (Vygotsky, 1978; 1993).

In this study, another theoretical framework used is the Experiential Learning Model (ELM) as explained by Kolb (1984) integrates Lewin's, Dewey's and Piaget's models of learning. Some similarities between these three models identified by Kolb are the idea of learning as a process, experience as its resource or input, and knowledge as being created through the learning process or output of the process. Based on these and other principles, Kolb proposes ELM as a four-stage cycle composed by concrete experience (CE), reflective observation (RO), abstract conceptualization (AC), and active experimentation (AE) (Figure 4). In his model, there are two distinct ways of grasping experience or prehension; one is abstract, called comprehension, and the other one is concrete or tangible, called apprehension.( Kolb, Boyatzis, \&Mainemelis, 2001), when talking about experiential learning, state that in each experience people either receive information concretely by "experiencing the concrete, tangible, felt qualities of the world relying on our senses and immersing ourselves in concrete reality" (p. 228), or receive it in symbolic or abstract ways, not through our senses. The EL model also presents two different ways of transforming the experience; one is called intention which is transforming information by reflection, and the other is called extension which is transforming information by action (Kolb, 1984). 


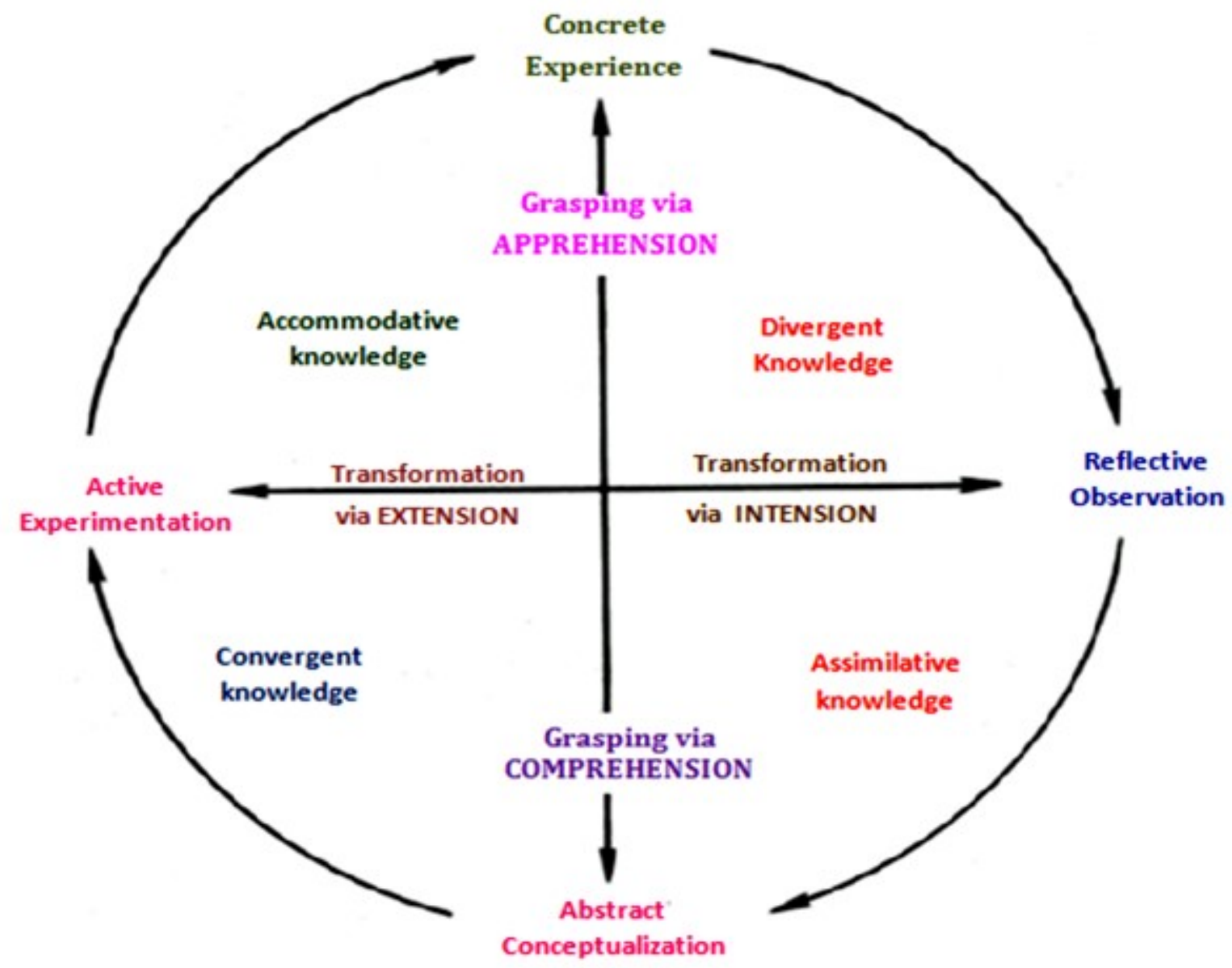

Kolb, David A., EXPERIENCTIAL LEARNING:

Experience as a Source of Learning \& development, (C1984, p.24.

Figure 3: Experimental Learning Cycle.

Neither prehension nor transformation by themselves produces knowledge, but both are needed for learning to occur (Kolb, 1984). Kolb (1984) states that "the simple perception of experience is not sufficient for learning; something must be done with it. Similarly, transformation cannot represent learning, for there must be something to be transformed, some state or experience that is being acted upon" (Kolb, 1984, p 42).

Bruner introduced the concept of learning by discovery. Bruner is of the view that learning is effectively engaged in if the learner is given the opportunity to discover facts by him/herself. Bruner argues that mere presentation of information will not enhance effective solution of a problem. The theory stresses cognitive effectiveness. Because of this, some referred to Bruner's theory of learning as Bruner's theory of cognitive development.
Bruner believed that learning by discovery begins when science teacher purposefully (i.e. intentionally) create (present) a problem and present it to the students by introducing some inconsistencies (i.e. contradictions) among the source of information which is given in the process of instruction. According to Bruner such inconsistencies lead to intellectual discomfort that will stimulate (i.e. motivate) the students to initiate individual discoveries through cognitive restructuring (i.e. internal reorganization). The intellectual discomfort created by the inconsistencies makes the learner to attempt to bring order out of this confusion by engaging in mental processes i.e. discovery activities which involve observation, hypothesizing, measuring, stating problem, data collection, classifying, inferring, etc. Through mental processes, the student can generate facts from his/her desperate experiences. 
Experiences gained during the mental processes enable the students to sense the disparity.

Piaget's cognitive theory of learning refers to the stage theory of cognitive development. According to Piaget, children develop knowledge by inventing or constructing reality out of experience and thus mix their observation with their ideas about how the world works. Piaget observed that people of the same age level (especially children) have a similar line of reasoning. For instance, children of the same age level have similar line of reasoning or thinking. Children may make the same type of mistakes. They may have the same reasoning process. This indicates that cognition develops stage by stage. Piaget used the terms 'Assimilation' and 'Accommodation' to explain his views.

Assimilation: Assimilation means a process of interpreting actions or events in relation to one's schemas. This refers to a means of fitting reality into one's existing structures of knowledge. The term 'schemas', for Piaget, refers to a well-defined sequence of physical and mental actions.

Accommodation: This is the modification of existing schemas to fit reality. The organism is capable of learning when it can modify its schemas. As the organism continues to accommodate, it continues to learn. Piaget believes that cognition develops from age to age and from level to level. According to Piaget, the driving force for cognitive development is equilibration. By equilibration, Piaget means balancing assimilation and accommodation to adapt to the demands of the environment.

\section{Information Processing Model}

The use of tools, specifically Instructional Resources, is supported in theory by cognitive information processes. According to cognitive information processes (Bourne, Dominowski, Loftus, \& Healy, 1986; Ormrod, 2004), we receive information through our senses and some of that information is stored in working memory. This process occurs because attention is given to that information. Once information is in working memory, it can be encoded and transferred to long-term memory (Ormrod, 2004).

However, there is a two-way interaction between working memory and long-term memory. Information is encoded to be transferred to long-term memory, and information is being retrieved from long-term memory to working memory (Ormrod, 2004).
The study discusses this model and relates it to Instructional Resources use in teaching/learning mathematics below. Senses can receive an unlimited amount of information that stay in sensory memory in the same way it was received (visual, tactile, etc.) (Bourne et al., 1986; Ormrod, 2004). Sensory information stays there for a very short time, although there are disagreements on the amount of time. For example, according to (Ormrod, 2004), information remains in the sensory register for no more than four seconds. She states that auditory information may last between two and four seconds.

Several studies have been conducted on the use of instructional materials and resources for science teaching. There has been little or no study done on use of instructional resources as correlates of the teaching of mathematics mostly in the context of Cameroon. This study seeks to explore the influence of instructional resources on the teaching of mathematics in the South West region of Cameroon. Efforts have been made by other scholars severally in addressing issues related the use of instructional resource in the teaching of mathematics in other parts of the globe, which are hereby recapitulated by this study as seen below.

Bisiriyu (2016) investigated Instructional Materials as Correlates of Students' Academic Performance in Biology in Senior Secondary Schools in Osun Statein Nigeria. The sample used for the study consisted of 40 students who were randomly selected from two different secondary schools in Ilesa East Local Government area in Osun State. 20 Students were used for experimental group while the other 20students were under the control group. Quantitative method was used to collect data by using the research questions and hypotheses formulated for the study. Research instrument used for the study consisted of Biology Achievement Test (BAT). This BAT contained a 50 multiple choice items. A reliability coefficient of 0.82 was obtained for BAT, using Testretest method. Data collected were analysed by using mean score, standard deviation and T-test distribution. Findings revealed that students taught with instructional materials performed better than those taught without instructional materials. That is the experimental group performed better than the control group (t-calculated value, 3.94 $>\mathrm{t}$-critical value2.02). It was further revealed that there is no significant difference between pre-test scores and post-test scores of experimental group (t-critical value, 2.02> tcalculated value-2.79). The post test scores of male 
and female students taught with instructional materials showed no significant difference between their scores ( $\mathrm{t}$-critical value, $2.10>\mathrm{t}$-calculated value, 1.33). Based on these findings appropriate recommendations were made as follow:

Considering the results got from the study, the following recommendations are hereby suggested:

1. Teachers should be encouraged to make use of different instructional materials as long as they are relevant to their lesson contents.

2. In case these instructional materials are not available, government should assist schools financially so that these teaching aids are purchased.

3. A situation where ready -made instructional materials are insufficient, these should be supplemented with improvised instructional materials.

4. For any teacher to make use of improvised instructional materials there is need for such teachers to be resourceful in material selection and planning.

5. Government should assist schools by organizing seminars and workshops for Biology teachers to enrich their knowledge about improvisation.

6. Government should periodically check the instructional materials supplied to schools through the Education inspectors to ensure proper use of these materials.

\section{METHODOLOGY}

This chapter presents a picture of issues related to the methodology involved in the study. The issues include research design, area of the study, population of the study, sample and sampling technique, data collection instruments, reliability and validity of instruments, administration of the instrument, ethical issues, data analysis.

This study subscribed to a descriptive survey research design. Survey research is considered a method of systematic data collection (Borg \& Gall, 1989, p. 416). The purpose of survey research is to describe specific characteristics of a large group of persons, objects, or institutions (Jaeger, 1988, p. 303). Surveys are one of the most commonly used methods of descriptive research in education than the other behavioural sciences. A survey involves the gathering of limited data from a relatively large number of cases at a particular time. This method is frequently employed to indicate prevailing conditions or particular trends. It is not concerned with characteristics of individuals as individuals, but it is concerned with providing information about population variables (Verma \& Beard, 1981, p. 59). Nworgu (1991, p. 55) observed that in survey research a group of people or items are studied by collecting and analyzing data from only a few people or items considered to be representative of the entire group.

Key informants were sampled only in the South West region of Cameroon. No gender discrimination as males and females were involved in the study.

The population of this research was all mathematics teachers and students in public English Speaking Secondary schools in the South West Region of Cameroon. The target population is all the mathematics teachers, form five and upper sixth students.

\section{Table 1: Distribution of Public English Secondary Schools in the South West Region.}

\begin{tabular}{|l|l|l|l|l|l|}
\hline \multicolumn{1}{|c|}{ Division } & GHS & GBHS & GSS & GBSS & Total \\
\hline $\begin{array}{l}\text { FAKO } \\
\text { Scientic }\end{array}$ & 17 & 7 & 6 & 00 & 30 \\
\hline $\begin{array}{l}\text { KUPE / M } \\
\text { and }\end{array}$ & 4 & 4 & 12 & 3 & 23 \\
\hline $\begin{array}{l}\text { LEBIALEM } \\
\text { Mnent }\end{array}$ & 9 & 30 & 6 & 3 & 21 \\
\hline $\begin{array}{l}\text { MANYU } \\
\text { MEME }\end{array}$ & 10 & 2 & 26 & 3 & 41 \\
\hline $\begin{array}{l}\text { NDIAN } \\
\text { GRAND }\end{array}$ & 57 & 24 & 92 & 10 & 183 \\
TOTAL & & 3 & 17 & 0 & 43 \\
\hline
\end{tabular}

Source: List of Schools Operating in the South West Region 2015/2016.

Service of School Maps Guidance and Counselling and Co-Curricular Activities, RDSE/SW (Regional Delegation of Secondary Education/ South West).

Two schools were sampled per division, one urban and one rural making a total 12 schools. By working with all the divisions, while making sure that schools from both rural and urban settings are represented ensure the geographical representativeness of the sample. 
The target population is form 5 and upper sixth students. They are targeted because they are in examination classes and have a major objective to attain. As a result of this, they are more likely to be conscious and critical as far as teaching and learning is concerned. These students will answer the questionnaire items and provide their results of the first term in mathematics. If it is estimated a total of 50 form 5 and 50 upper sixth students per school, then the total target population of students is $(183 \times 50) *$ $2=18300$ students in a multi-stage sampling perspective. The sample size was estimated probabilistically from this population.
The choice to put into use the simple random sampling in this study is because it is by far the easiest and simplest probability sampling technique in terms of conceptualization and application. It does not necessarily require knowledge of the exact composition of the population, so long as we have an exhaustive data base for the population and can reach all the members of that population. This was the case for the schools and the students. Where such condition was not met, as it was the case with the teachers, convenience sampling was used as the closes alternative to simple random sampling.

Table 2: Distribution of schools per division

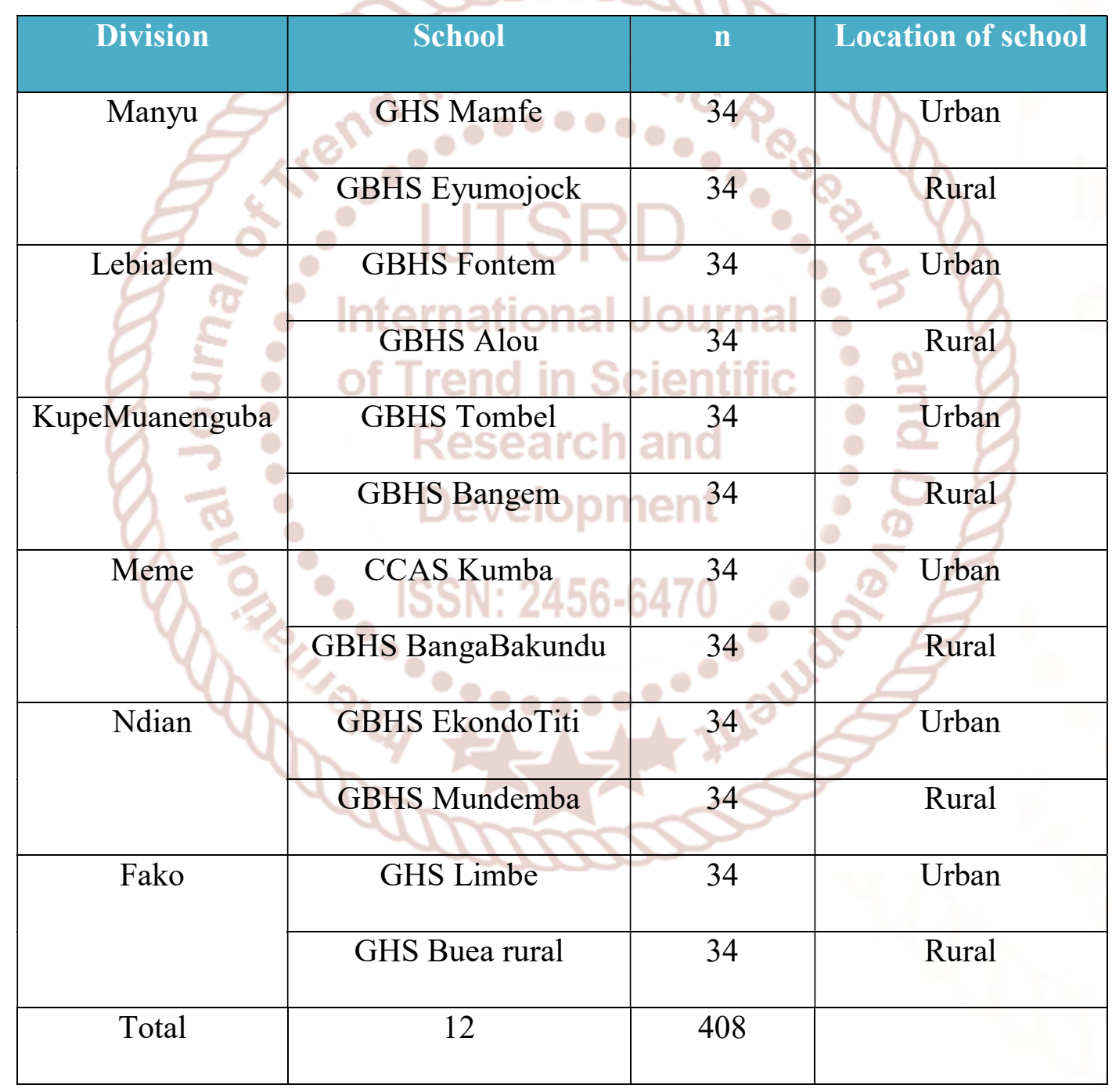

Students were sampled from 12 schools, making a total of 34 students per school. Half of the schools were from urban area and the other half from rural area. 
International Journal of Trend in Scientific Research and Development (IJTSRD) ISSN: 2456-6470

Schools involved in Focus group Discussions

Table 3: Schools involved in focus group discussion

\begin{tabular}{|c|c|c|c|}
\hline $\mathbf{S} / \mathbf{N}$ & $\begin{array}{l}\text { NAME OF } \\
\text { SCHOOL }\end{array}$ & DIVISION & $\begin{array}{l}\text { Number of } \\
\text { participants }\end{array}$ \\
\hline 1 & $\begin{array}{c}\text { GBHS } \\
\text { MUNDEMBA }\end{array}$ & NDIAN & 8 \\
\hline 2 & $\begin{array}{c}\text { GBHS } \\
\text { BANGEM }\end{array}$ & $\begin{array}{c}\text { KUPE } \\
\text { MUANENGUBA }\end{array}$ & 8 \\
\hline 3 & $\begin{array}{l}\text { CCAST } \\
\text { KUMBA }\end{array}$ & MEME & 8 \\
\hline 4 & $\begin{array}{c}\text { GBHS } \\
\text { FONTEM }\end{array}$ & LEBIALEM & 8 \\
\hline 5 & $\begin{array}{c}\text { GBHS } \\
\text { EYUMOJOCK }\end{array}$ & MANYU & 8 \\
\hline 6 & $\begin{array}{l}\text { GHS BUEA } \\
\text { RURAL }\end{array}$ & FAKO & \\
\hline
\end{tabular}

\section{Instruments for Data Collection}

The study employed multiple methods of data gathering which involve a combination of quantitative and qualitative ways of data collection. According to Sommer and Sommer (1980), multi-method approach of data gathering is used to probe more deeply into significant issues inherent in the variables under investigation and to contribute to a ebetter understanding and the interpretation of the research findings.

Quantitative data were collected through the administration of a set of semi-structured questionnaire. Qualitative data were collected through interviews, focus group discussions, open-ended questions and classroom observational checklist. Providing students, teachers, school administrators and educational administrators the opportunity to speak during interviews would give the researcher a better understanding of the participants' attitudes and perceptions in mathematics classrooms. The interviews are intended to provide a better insight about the feelings of the learners and the teachers toward the effectiveness of instructional resources in teaching mathematics as well as determining whether the interventions are worth being sustained.

\section{Questionnaire}

Questionnaire was used in order to generate adequate amount of quantitative data because it will be impossible for the researcher to have all the time at his disposal. Moreover, structured questionnaire was used in this study because researchers have argued that they are quicker to code and analyse than wordbased data within a short time frame (Cohen, Manon, \& Morrison, 2007).

\section{Classroom Observational Checklist (COCL)}

Observational checklists for the use of instructional resources in schools allow researcher to deeply investigate and probe issues, thoughts, perceptions, feelings and perspectives which are not easily measured quantitatively (Wellington, 2000). An observational checklist for students for qualitative data collection will be used in this study.

\section{Validity of Instruments}

Before the final administration of the instrument during the main study, efforts were made to ensure the validity of the instruments. The quality of research is related to the possession of the quality of strength, worth, or value (Keeves, 1997, p. 279).

\section{FINDINGS}

The combined influence of the use of instructional resources in the teaching of mathematics on students' performances in mathematics was appraised using Logistic Regression Model thus making the Integrated Value Mapping (IVM). The variability explained by the IVM was not significant (Model fitting information: $\left.\chi^{2}=34.776 ; \quad \mathrm{P}=0.431\right)$. This therefore implies that the aggregated influence of the four categories of instructional resources considered in this study on students' performances in mathematics was not significant. In a nutshell, they contribute insignificantly to students' performances in mathematics given the very weak Explanatory Power (EP) / Predictive Power of 8.8\% (Cox \& Snell R Square $=0.088$ ).

Table 36: Model Fitting Information and Model Explanatory Power

\begin{tabular}{|c|c|c|c|c|}
\hline \multirow{2}{*}{$\begin{array}{l}\text { Omnibus Tests of } \\
\text { Model Coefficient }\end{array}$} & \multicolumn{3}{|c|}{ Likelihood Ratio Tests } & \multirow{2}{*}{$\begin{array}{l}\text { Explanatory/predictive power of the } \\
\text { model (Pseudo R-Square) based on } \\
\text { Cox and Snell* }\end{array}$} \\
\hline & Chi Square & df & Sig. & \\
\hline$\chi 2=34.776$ & & & & \multirow[t]{2}{*}{0.088} \\
\hline $\begin{array}{c}\mathbf{d f}=\mathbf{3 4} \\
\mathrm{P}=\mathbf{0 . 4 3 1}\end{array}$ & 35.977 & 34 & 0.376 & \\
\hline
\end{tabular}

*Dependent variable: Score in mathematics. 


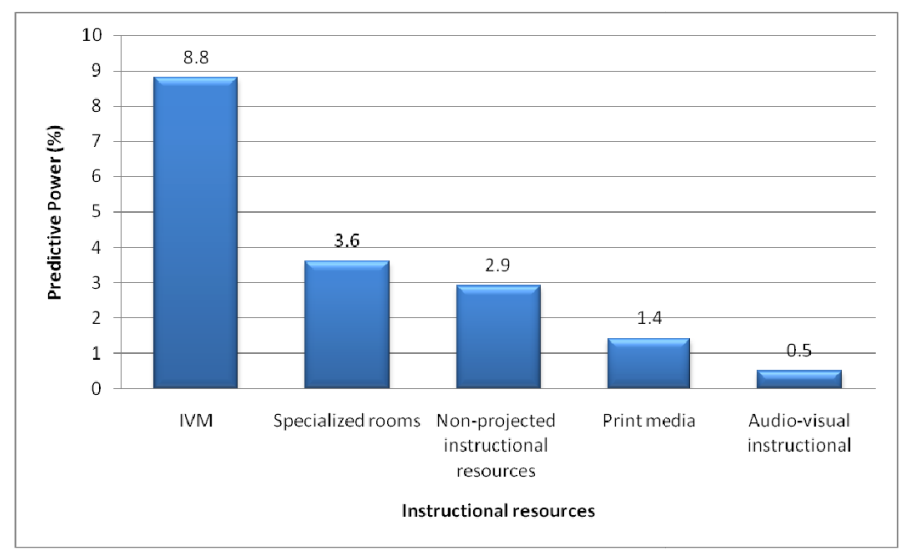

Figure 5: Comparing predictive effects of categories of instructional resources on students' performance in mathematics.

Specialized rooms had the highest influence on students' performances in mathematics with a Predictive Power of 3.6\%. This is followed by nonprojected instructional resources $(2.9 \%)$, print media (1.4) and the least being audio-visual instructional resources $(0.5 \%)$. The aggregated influence or Integrated Value Mapping (IVM) was $8.8 \%$. Thus implying that there was roughly $91 \%$ of variability not explained. Conclusively, besides the strategies considered in this study context to enhance students' performance in mathematics, there are other factors not considered in this study that to a very great extent determine students' performances in mathematics and these factors account for almost $91 \%$ of the missing variability. In addition to this, it is clear that the aggregated influence of the categories of instructional resources more than individual influence determined students' performance in mathematics better though not significantly, given that it has the highest Explanatory/Predictive Power.

\section{Conclusion}

This study investigated the influence of the use of instructional resources in the teaching of mathematics on students' performance in mathematics in public English speaking secondary schools in the south west region of Cameroon. The focus of the study was on students in public English speaking secondary schools in the South West region of Cameroon. The schools are located in rural and urban areas in the six divisions of the South West region of Cameroon. There were basically three instruments developed by the researcher, namely; mathematics students' questionnaire (MSQ), focus group discussions (FGD) and classroom observational checklist (COCL). These instruments were designed to measure the influence of the use of instructional resources in the teaching of mathematics on students' performance.

The results of this study indicated that students' performance in mathematics was not significantly influenced by the use of print media instructional resources, non-projected instructional resources, specialized rooms and projected /audio-visual instructional resources in the teaching of mathematics. The findings further showed that the textbook was the most used instructional resource by teachers in classrooms. The findings of this study also demonstrated by the Logistic Regression that the mean performance of students in urban areas was slightly higher than students in rural areas on the influence of the use of instructional resources in the teaching of mathematics on students' performance in mathematics. Moreover, findings of this study indicated that no display instructional resources were ever seen by students in classrooms during instruction. Findings from this study suggest that students have the impression that teachers talking to them directly is better than using audio-visual instructional resources during mathematics instruction. They however expressed a high need for computer and mathematics laboratories.

However, students across the 06 divisions acknowledged the non-existence of mathematics laboratories in their schools, be them in the urban or rural areas. This study thus revealed that computer laboratories in schools were rather used for computer science instruction and information communication technology (ICT) than in mathematics instruction.

It is equally evident from the findings of the study that for the most part, mathematics is not at all taught using model instructional resources in schools.

Although learners' belief about innovations is important, without the teacher's positive support, learners may find it uneasy to explore instructional resources in mathematics instruction desired to enhance their learning outcomes. From the results of this study, it is reasonable to suggest that the use of instructional resources in mathematics instruction is the best teaching strategy to facilitate learners' active engagement in the lesson, notably computer and mathematics laboratories. Such pedagogical approach increases responses to questions, improved communicative competence, immediate feedback and increased attention to what is going on in the classroom. Similarly, the use of instructional 
resources in mathematics instruction has been claimed to ease the teacher's workload and enhance teacher and learners' effectiveness in the classroom.

It is therefore hoped that the outcomes of this study have provided significant insights on the influence of the use of instructional resources in the teaching of mathematics on students' performance in mathematics in public English speaking secondary schools in the south west region of Cameroon. The study may have also provided convincing evidence to support the efficacy of the textbook in instruction, blended with other instructional resources, as a better teaching strategy for mathematics instruction in Cameroon secondary schools.

\section{Recommendations}

Everybody is born with the attributes to learn mathematics, but the ability to effectively learn must be accompanied by appropriate teaching methods. In view of the findings of this study, it is recommended that:

the ministry of secondary education in Cameroon and other education stakeholders should collaborate to encourage teachers' adoption and successful integration of multidimensional pedagogies, such as the use of instructional resources such as print media, non-projected/ display instructional resources, projected/audiovisual instructional resources in the teaching of mathematics. It is hoped that the adoption and integration of the aforementioned instructional resources would blend the instructional process. These instructional resources would greatly enhance the quality of instruction and the quantity of students' performance. The use of instructional resources in mathematics instruction is still at the infancy stage in Cameroon.

$>$ One area that may be of concern to the stakeholders in the education sector in the South West region and Cameroon is how to build the capacity of the teachers to enable them to effectively integrate the use of instructional resources in mathematics instruction classrooms. Probably, strategic plans on how to engage teachers in capacity building programmes relating to effective integration of the aforementioned instructional resources should be considered.

Moreover, teachers' certified attendance and ability to demonstrate effective transfer of knowledge, gained from the capacity building programmes, into mathematics classrooms with the use of instructional resources. This aspect may be considered as a major prerequisite to teacher's annual appointments and promotions. Perhaps expertise knowledge about the best practices relating to the use of instructional resources in mathematics instruction may be considered to further encourage teachers' adoption of instructional resources such as print media, nonprojected/ display instructional resources, projected/audio-visual instructional resources in the teaching of mathematics.

\section{REFERENCES}

1. Adeogun, A. A. (2001). The principal and the financial management of public secondary schools in Osun State. Journal of Educational System and Development.5(1), pp.1 - 10.

2. Atkinson, R. K. (2000). Learning from Examples: Instructional Principles from the Worked Examples Research. Mississippi State University.

3. Ayot, H. O. (1984). Language for learning. Nairobi: Macmillan publishers.

4. Bisiriyu, A. A. (2016). Instructional Materials as Correlates of Students' Academic Performance in Biology in Senior Secondary Schools in Osun State in Nigeria.

5. Borg, W. R. \& Gall, M. D. (1989).Educational Research: An Introduction. Fifth Edition. New York: Longman.

6. Bournne, L., Dominowski, R., Loftus, E. F., \& Healy, A. F. (1986).Cognitive Processes.

Englewood Cliffs, NJ: Pretice-Hall, Inc.

7. Cohen, L., Manion, L., \& Morrison, K. (2007).Research methods in education (6th ed.). USA, Canada: Routledge.

8. Downing, S. M. (2004). Reliability: On the producibility of assessment data. Medical Education, 38, 1006-1012.

9. Fennema, E., \& Franke, M. (1992).Teachers' knowledge and its impact. In D. A. Grouws (Ed.), Handbook of research on mathematics teaching and learning: A project of the National Council of Teachers of Mathematics (pp. 147-164). New York, NY, England: Macmillan Publishing.

10. Fuller, B. (1986)." Raising school quality in developing countries. What investment boosts learning?" The World Bank discussion paper, 
Education and training series. New York: Praeger Publishers.

11. Gogo, K.S. (2002). "Input of cost sharing on access, equity and quality of secondary education in Rachuonyo District". Unpublished ME.d. Thesis, Kenyatta University.

12. Greeno, J. (2003). Situative research relevant to standards for school mathematics. In J. Kilpatrick, W. G. Martin, \& D. Schifter (Eds.), A research companion to principles and standards for school mathematics (pp. 304-332). Reston, VA: National Council of Teachers of Mathematics.

13. Hiebert, J, Carpenter, T. P., Fennema, E., Fuson K.C., Wearne D., Murray, H., Olivier, A., \&

14. Human, P., (1997). Making sense: Teaching and learning mathematics with understanding. Portsmouth, NH: Heinemann

15. Hiebert, J. (2003). What research says about the NCTM Standards. In J. Kilpatrick, W. G. Martin, \& D. Schifter (Eds.), A research companion to principles and standards for school mathematics (pp. 5-23). Reston, VA: National Council of Teachers of Mathematics .

16. Jaeger, R. M., (Ed) (1988). Complementary Methods for Research in Education. American Educational Research Association. Washington, DC.

17. Keeves, J. P., (Ed) (1997). Educational Research, Methodology, and Measurement: An International Handbook. Second Edition. Pergamon.

18. Klein, D. (2007). A quarter century of U.S. 'math wars' and political partisanship. Journal of the British Society for the History of Mathematics, 22, 22-33.

19. Kolb, D. A. (1984). Experiential learning. Englewood Cliffs, NJ: Prentice-Hall, Inc.

20. Kolb, D. A., Boyatzis, R. E., \& Mainemelis, C. (2001). Experiential learning theory: Previous research and new directions. In Sternberg, R.J. \& Zhang, L. (Eds.), Perspectives on Thinking Learning, and Cognitive Styles (p 227-247) Mahwah, NJ: Lawrence Erlbaum Associates.

21. Lantolf, J. P. (2000). Introducing sociocultural theory. In J. P. Lantolf (Ed.) Sociocultural theory and second language learning, (pp. 1-26). Oxford: Oxford University Press .
22. Mewborn, D.S., \& Cross, D.I. (2007). Mathematics teachers' beliefs about mathematics and links to students' learning. In W. G. Martin, M. E.

23. Miller, M. J., Ryan, C. E., Bishop, D. S., \& Epstein, N. B. (2000).Mc master approach to families: Theory, assessment treatment and research. Journal of Family Therapy, 22(2), 168189.

24. Muthamia, H.N. (2009). Factors affecting Adult Education Learners recruitment programme in Kakamega south district, Kenya. Unpublished M.Ed. Thesis, Masinde Muliro University.

25. Nworgu, B. G. (1991). Educational Research: Basic issues and methodology. Ibadan: Wisdom Publishers.

26. Ormrod, J. L. (2004). Human learning (4th Edition), Columbus, OH: Prentice Hall.

27. Ormrod, J. L. (2004). Human learning (4th Edition), Columbus, $\mathrm{OH}$ : Prentice Hall.

28. Schoenfeld, A. H. (2004). The math wars. Educational Policy, 18(1), 253-286.

29. Sommer, B. \&Sommer, R. (1980).A practical guide to behavioural research: Tools and technique (4th ed.). NY: Oxford University Press.

30. Verma, G. \& Beard, R. (1981). What Is Educational Research. Londres: Gower.

31. Vygotsky, L. S. (1993). The fundamentals of defectology: Abnormal psychology and learning Disabilities. In R. W. Rieber \& A. S. Carton (Eds.), The Collected Works of L. S. Vygotsky, (2nd ed., pp. 1928-1933). NY: Plenum Press.

32. Vygotsky, L.S. (1978). Mind in society: The development of higher psychological lprocess. Cambridge, Massachusetts: Harvard University Press.

33. Wellington, J.(2000). Educational research: Contemporary issues and practical approaches. London: Biddles Ltd, King's Lynn Nortfolk. 